Executive Committee of the Uganda Biosphere Club

Chairman: Mr Edward E.S. Musaka

Vice-Chairman: Mr Paul Okitoy

Secretary-General: Mr David Nkwanga

Secretary: Miss Ruth Abwot

Treasurer: Mr John Mwesigwa
Member: Miss Margaret Nambi

Member: Mr Mathias Serugo

David Nkwanga, Secretary-General

The Uganda Biosphere Club

P.O. Box 9932

Kampala, Uganda.

\title{
Soaring Temperatures in Ghana?
}

$S^{t}$ tephens (1995) recently reported that temperatures in Ghana were increasing during this century and that the temperature rise could be evidence of a global warming signal. Using data from 11 stations, Stephens shows that the temperatures in the 1961 to 1990 period were higher than temperatures in the 1930 to 1960 period, noting that, between 1945 and 1990, temperatures in Ghana were "soaring' upwards; suggested causes included the 'greenhouse' effect and the potential influences of urbanization. While I commend Stephens for the effort, I conducted the following research that may be of interest to individuals concerned with regional climate changes over the period of reliable historical records.

I collected the 1945 to 1994 monthly temperature anomaly data from the widely-used Jones (1994) data-set for the $5^{\circ}$ latitude by $5^{\circ}$ longitude grid cell that contains most of Ghana (centred on $7.5^{\circ} \mathrm{N}, 2.5^{\circ} \mathrm{W}$ ). A plot of the 12 months' smoothed anomalies (Fig. 1) shows variability from year to year, but absolutely no evidence of any 'quite significant soaring of temperatures'. From 1945 to 1994 , the temperatures in this grid cell actually cooled slightly, but at a statistically insignificant rate. From 1945 to 1990 , there is simply no warming in the record.

The satellite-based lower-tropospheric temperature data developed and described by Spencer \& Christy (1990) provides another opportunity for testing temperature trends in Ghana. I collected the updated satellite data for the five $2.5^{\circ}$ latitude by $2.5^{\circ}$ longitude grid cells that cover Ghana for the period 1979 to 1994 , then smoothed the data using a 12-months filter, and plotted the data in Fig. 1. The satellite-based lower-tropospheric temperature data reveal a statistically highly significant cooling of $0.027^{\circ} \mathrm{C}$ per year over the period of record.

Although Ghana represents only $0.05 \%$ of the Earth's surface, it is important to analyse temperature trends even at this spatial scale. Stephens has shown that the temperatures at 11 stations in Ghana have increased since the end of World War II. However, this warming signal does not appear in the widely-used Jones (1994) data and it is certainly not found in the updated satellite-based Spencer \& Christy (1990) lower-tropospheric temperature data.

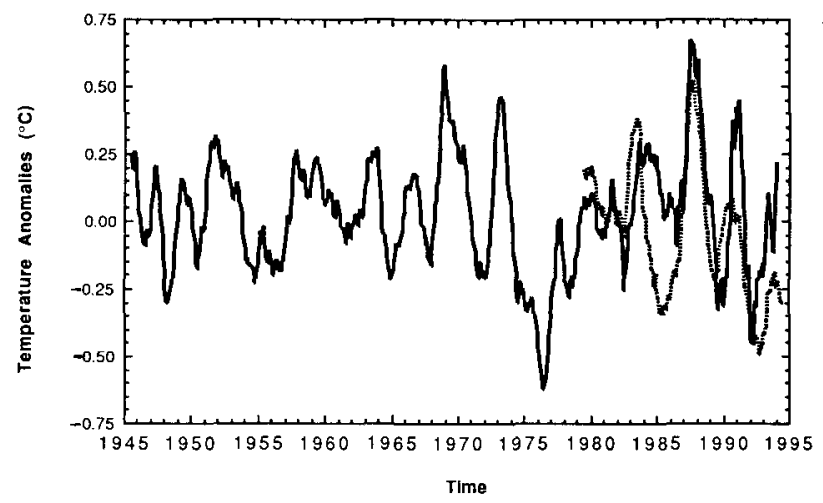

FIG. 1. Ghana monthly temperature anomalies based on the Jones (1994) near-surface air temperatures (solid line) and updated Spencer \& Christy (1990) satellite-based lower-tropospheric temperature measurements (dotted line).

While there may be any number of causes for the patterns reported by Stephens, it seems likely that the reported temperature rise in Ghana is more related to local urbanization effects than to any regional signal associated with the buildup of 'greenhouse' gases.

\section{REFERENCES}

JONES, P.D. (1994). Hemispheric surface air temperature variations: A reanalysis and an update to 1993. Journal of Climate, 7, pp. 1794-1802, illustr.

SPENCER, R.W. \& ChRISTY, J.R. (1990). Precise monitoring of global temperature trends from satellites. Science, 247, pp. 1558-62, illustr.

STEPHENS, C.E. (1995). Some indications of global warming in Ghana. Environmental Conservation, 22(2), pp. 174-5 \& 166, illustr.

Robert C. BAlling, Jr, Director

Office of Climatology

Department of Geography

Arizona State University

Tempe

Arizona 85287, USA.

\section{UN Recommendations on Transport of Dangerous Goods}

$\mathrm{D}$ uring the past 40 years, the 'Orange Book' has been a 'must' for all public authorities, carriers, and consigners handling substances which are hazardous for people and/or the environment. This 'United Nations Recommendations on the Transport of Dangerous Goods ${ }^{*}$ has become the generally acknowledged source of technical provisions, which are now implemented world-wide. Many Governments in all inhabited continents have based their national legislation on these recommendations, and their implementation is also guaranteed through international conventions regulating all modes of transport - whether by road, rail, inland waterways, air, or maritime shipping.

*Recommendations on the Transport of Dangerous Goods, Ninth revised edition. United Nations, New York and Geneva, ISBN 92-1139084-6, ISSN 1014-5753, UN Sales Nr E.95.VIII.1, Price US \$95. Also available on diskette (Sales Nr 94.VIII.2, Price US \$250.)
All the dangerous substances and articles that are most commonly carried are listed in this 'Orange Book'. They are divided into nine classes: namely 1 Explosives; 2 Gases; 3 Flammable liquids; 4 Flammable solids; 5 Oxidizing substances and organic peroxides; 6 Toxic and infectious substances; 7 Radioactive material; 8 Corrosive substances; and 9 Miscellaneous dangerous substances and articles.

The 'Orange Book' contains provisions for packing dangerous goods, marking and labelling packages, placarding transport units, and shipping documentation. It also includes provisions for the construction of packagings, intermediate bulk containers, multimodal tank-containers, as well as for their testing and approval.

The ninth revised edition of the 'Orange Book' has recently been published in English but will, at a later stage, 